\title{
Letter from the Editor: The Incredible Shrinking Century?
}

Is "presentism" a "bad thing"- a historiographical sin? That is a claim I have heard since graduate school, and it is one usually made by those who work on ancient history, i.e., the time before, say, 1945! As a historian of the post-World War II period, I have always felt a tinge of guilt for focusing my attentions on issues that ostensibly have a greater bearing on today's world - and that (I speak from experience) medievalists and early modernists see as somehow less high-minded for that! Imagine, then, my great surprise to read in many of the contributions to this issue's special discussion forum, "The Vanishing Nineteenth Century in European History," that this is a period still worthy of our interest not least because of the importance of phenomena and developments associated with that century for the present. That is not the sole reason proffered, but it is one that runs like a red thread through many of the contributions. ${ }^{1}$

According to organizers Karen Hagemann and Simone Lässig, the recent attention drawn to the declining number of scholarly articles, conference papers, and published monographs on the nineteenth century was an important catalyst for the forum. The fourteen participants they brought together discuss a variety of reasons for this trend and, at the same time, usefully suggest possible themes and areas for future research that will, they believe, help reinvigorate and fortify the field. Six of the participants focus on regional histories: David Blackbourn, James M. Brophy, and Pieter Judson on German-speaking Central Europe; Alexander Martin, Lloyd S. Kramer, and Alex Chase-Levenson on Russia, France, and Britain, respectively. Five turn their attention to specific approaches and subfields: Roger Chickering on military history, Simone Lässig on Jewish history, Suzanne Marchand on cultural and intellectual history, Karen Hagemann on women's and gender history, and Sebastian Conrad on colonial history. Birgit Aschmann, Jürgen Osterhammel, and Andrew Zimmerman kindly provided concluding comments.

It is worth emphasizing that several of the participants have a much more sanguine view of the state of their field. But if it is true that scholarly interest in the nineteenth century is dissipating — all things being relative — one conclusion one might take away from the contributions to this forum is that the scholarship on the nineteenth century has been a victim of its own success. As Hagemann and Lässig put it in their introduction:

The nineteenth century became seemingly less relevant when the Holocaust and post-1945 memory of it replaced the search for the roots of National Socialism in the century before 1933 as the focal point of research. This trend was reinforced by the general rejection of the Sonderweg [special path] thesis by the generation of historians who entered the profession beginning in the late 1980s. As a result, it apparently became less necessary to study the nineteenth century if one wanted to understand the "Age of Extremes."

In other words, the vanishing attention to the period is a direct result of the changing "vanishing point" (Helmut W. Smith) of our scholarly attention-a result, in turn, of the

${ }^{1}$ For a stimulating discussion, see the special section "Viewpoints: Presentism," in Past $E$ Present 234, no. 1 (2017): 213-89. 
pioneering work by Blackbourn and others that made the Sonderweg thesis seem less compelling in the first place.

But to return to the question at the outset: is presentism a sin? As I have written previously in these pages, such parochial debates seem less important if one thinks of the study of the past - or of any humanist endeavor - as akin to thrusting one's head inside a giant bubble: wherever and however one thrusts should afford some glimpse and greater understanding of humanity-regardless of one's concerns or thematic focus, one's method or approach. If one's interest in the past is guided by a concern for the present, so be it. And if one wishes to study the past purely "for its own sake," that is an equally worthwhile undertaking.

ANDREW I. PORT

EDITOR 